\title{
Haydn Biography by a Milanese Musician from the Time of the Napoleonic Wars
}

\author{
Katalin SzERZŐ \\ Hungarian Academy of Arts \\ Pf. 242, H-1368 Budapest, Hungary \\ E-mail: szerzo.katalin@gmail.com
}

(Received: September 2016; accepted: November 2016)

\begin{abstract}
The article discusses the German translation of Giuseppe Carpani's Haydn biography of 1812. While notes on Haydn by the two German biographers Dies and Griesinger are regularly quoted and considered authentic despite the fact that their authors were good observers but not musicians, musicology pays little attention to the third contemporary Haydn biography by the musician Carpani (1752[?]-1825). He was looked upon with distrust and it reflected on him in intellectual circles that his book on Haydn was plagiarized under a pseudonym right after its publication by an author who later acquired world fame as Stendhal.
\end{abstract}

Keywords: Giuseppe Carpani, Joseph Haydn, biography

"Haydn hat wie Columbus den Weg zu einer neuen Welt erschlossen, deren Existenz mehr oder weniger nur vermutet wurde..."

The events of the Haydn bicentenary had a personal gift for me: a book of agreeable size fitting even a lady's handbag which I discovered and bought at a bookshop in Eisenstadt during the intervals of the Haydn festivities in spring 2009. It was Giuseppe Carpani's famous-infamous Haydn biography of 1812 translated into German and provided with a scholarly preface by Johanna Fürstauer; it was published by Residenz Verlag on Nikolaus Harnoncourt's recommendation. Thus

1. Giuseppe Carpani, Haydn. Sein Leben. Aus dem Italienischen und mit einem Vorwort von Johanna Fürstauer. Geleitwort von Nikolaus Harnoncourt (St. Pölten-Salzburg: Residenz Verlag, 2009), 38. Henceforth reference will be made to the German translation of Carpani's book. 
the Italian work only accessible among the rarities of libraries has become widely available. $^{2}$

Giuseppe Carpani's work is the most disputed of the three contemporary biographical sources on Haydn. ${ }^{3}$ A survey of the Haydn literature makes it easy to prove that while notes on Haydn by the two German biographers Dies and Griesinger are regularly quoted and considered authentic - almost revelations despite the fact that their authors were good observers but not musicians, musicology pays little attention to the third contemporary Haydn biography by the musician Carpani (1752[?]-1825).

The question arises what the reason may have been. Contrary to the evidence of Dies, who was a painter, and of Griesinger, who was a diplomat by profession, these reservations must have to do with Giuseppe Carpani's path of life, full of contradictions. After 1815 news spread that he was a Habsburg agent of the time of the Holy Alliance, a committed supporter of the old-new European order consolidated after the Napoleonic wars. It had little weight that Carpani had the greatest artists of the time among his friends such as Haydn, Beethoven, Salieri, and Rossini who thought him worthy of their friendship. He was looked upon with distrust and it reflected on him in intellectual circles that his book on Haydn was plagiarized under a pseudonym right after its publication by an author who later acquired world fame as Stendhal. He pretended to be Haydn's friend of old age though he was not familiar with Haydn at all, published Carpani's book in French and as a queer side-effect of the whole plagiarism scandal, he thrust Carpani, the author of the original work, into the snare of suspicion. ${ }^{4}$

Notwithstanding, Giuseppe Carpani's biography of Haydn is a captivating, fascinating reading from the very beginning. Not for a moment does he get lost in detail, nor does he mince words. He clearly states in the first sentences who the hero of his work is: a man of no lesser importance than Joseph Haydn, a star in the Temple of Harmony, the father of instrumental music. ${ }^{5}$

Who was this Giuseppe Carpani? According to the introductory study he appeared in Haydn's environment at the time of the genesis of The Creation and warmed his way into the friendship of Haydn and the librettist Gottfried, Baron

2. Giuseppe Carpani, Le Haydine ovvero lettere sulla vita e le opere del celebre maestro Giuseppe Haydn (Milan: 1812).

3. A) Albert Christoph Dies, Biographische Nachrichten von Joseph Haydn. Nach mündlichen Erzählungen desselben entworfen und herausgegeben (Vienna: Camesina, 1810), B) Georg August Griesinger, Biographische Notizen über Joseph Haydn (Leipzig: Breitkopf und Härtel, 1810), new edition by Franz Grasberger (Vienna: Kaltschmid, 1954).

4. Cf. Louis-Alexandre-César Bombet [originally Marie-Henri Beyle, later Stendhal]: Lettres écrites de Vienne en Autriche sur le célèbre compositeur Joseph Haydn... (Paris: P. Didot l'aîné, 1814).

5. "Haydn! - Welch ein illustrer Name, dessen Ruhm wie ein Stern im Tempel der Harmonie erstrahlt. [...] der Vater der Instrumentalmusik, eine der phantasiereichsten Gestalten des 18. Jahrhunderts, der das Goldene Zeitalter der Musik geformt hat." Carpani, Haydn, 29. 
van Swieten as an intellectual co-author, the excellent Italian translator of the oratorio. $^{6}$

Carpani belonged to Mozart's generation even though he was his senior by four years. Born in Vilalbese, a small town of Lombardy, in 1752 (according to other sources in December 1751), he was educated by the Jesuits and after having finished reading the law he turned up in the environment of theatres as writer, librettist, musician, the Italian translator of French operas and plays. Lombardy was in those days, similar to the Kingdom of Hungary, part of the Danubian Habsburg Monarchy and Carpani was employed to general satisfaction from his early youth on as a theatrical general factotum in the theatre and opera workshop of the Archduke Ferdinand, heir to the crown and Governor of Milan, at his Monza summer residence. From 1792 to 1796 he was a famous and successful newspaper editor in Milan, the principal contributor to Gazzetta di Milano. In the issue of the fights going on the European political scene, he had to take sides explicitly: with his articles written first against the French revolution, later Napoleon, he joined evidently the party of the conservative Habsburg dynasty on the point of establishing itself in his country. He was a loyal supporter of order, opposed in principle to all upheaval.

It is small wonder that when Napoleon occupied Milan in 1796 Carpani fled to Vienna. There in the musical golden age of the Imperial city he could vanish from sight, mingle with people in the capital of the multinational Habsburg monarchy. It is true that Mozart was no more alive but Haydn, who had recently returned from his second London trip, Salieri, Beethoven and many others were still in town. Following the Treaty of Campo Formio in which Austria lost, among others, Lombardy and gained Venice, Istria and Dalmatia, Carpani was appointed director and censor of the Venice theatres in 1797. From that time on he presumably lived a double life and only settled in Vienna in 1804 once for all. ${ }^{7}$

If anyone wished to apprehend at the turn of the $18^{\text {th }}$ and $19^{\text {th }}$ centuries the still typical Central European literary mentality - the art of reading behind the lines -, one could hardly find a better and more enjoyable example than the biographical novel by this Lombardian musician written of the Austrian Haydn. It is rather an author's accomplishment than a Haydn monograph standing the test of

6. Carpani describes the story of their acquaintance in connection with the translations of The Creation in letter 11 as follows: "Es gibt zwei italienische Übersetzungen. Die eine wird allgemein nicht gut gefunden. Sie ist der in Paris gedruckten Partitur beigefügt und ist das Werk eines italienischen Improvisators, der keine Kenntnis der Musik hatte und die Verse so schrieb, wie sie kamen. Die zweite ist die einzige dieser Übersetzungen, die sowohl der Baron van Swieten als auch Haydn approbiert haben. Es wurde darin im musikalischen Text nicht eine Note verändert, und trotz des poetischen Stils ist es dem Autor gelungen, den Sinn des Originals gleichsam wörtlich wiederzugeben. Diese Übersetzung hat dem Autor den Vorzug der Freundschaft Haydns eingetragen und ihn in den Stand versetzt, so viel über seine Angelegenheiten und ihn selbst zu berichten. [My italics, Katalin Szerzö] ... Sie wurde von Artaria gedruckt, aber nur dem Klavierauszug beigefügt." Carpani, Haydn, 177.

7. See Johanna Fürstauer's scholarly introduction, "Vorwort," in Carpani, Haydn, 9. 
the reliability of the sources in each case. Nonetheless, it gathers with impressive practical knowledge music historical data from the composer and the people in his environment as well as from contemporary scholarly sources, letters, the press, and musical iconographies.

The 16 chapters dated 1808 to 1811 comprise an introduction and 15 fictitious literary letters. They are addressed to the educated European reader for whom the writer conjures up with colourful and vigorous strokes the image of his friend Haydn the way he revealed himself to a fellow musician, confided his secrets to him and as he had long known from his works and kept tally on. ${ }^{8}$

The biographical data from Haydn's childhood to his death and even beyond are embarrassingly treated as if they were merely of secondary importance. $\mathrm{He}$ writes somewhere that he is not a "flypaper" to collect meticulously all data. ${ }^{9}$ Nor is it his duty to decide who is right; for example when three eyewitnesses tell three different stories of the genesis of the Farewell Symphony. ${ }^{10}$ He frequently uses comparisons with the history of art keeping in mind that Haydn's Maecenas was the Esterházy family. The present patron Count Nikolaus II owned a world-famous picture gallery; the pictures found there ranged from Raffaelo to Tiepolo and proved to be his inspiring source all through the book. As a writer, Carpani was the painter of extensive surfaces and clear contours. He suggested his readers at every possible turn that the person he was writing about was one of the greatest geniuses of mankind, a musical counterpart to Columbus, Newton, and Tintoretto, the creator of entirely new genres: the classical symphony and the string quartet, the composer of masterpieces to be ranked among the greatest works of the history of European music.

How different this picture was from the "Papa Haydn" image of his fellow musicians and his immediate environment, a nickname already stuck to him by his contemporaries!

Carpani seeks with the excitement of a pragmatic journalist an answer to the question how a person born in a cottage in Rohrau on the Austrian-Hungarian border was able to become an appreciated citizen of the world associating himself on equal terms with members of dynasties and the greatest scholars and artists of the time - a "superstar" in the present meaning of the word - leaving to posterity the musical output of half a century, the remarkable masterpieces of the Viennese classicism.

8. "Carpani kannte Haydns Instrumentalmusik sehr genau, ebenso wie seine Messen, die er bei vielen festlichen Gelegenheiten in den zahlreichen Kirchen Wiens hören konnte." "Vorwort," in Carpani, Haydn, 23. - At the end of the first chapter, Carpani hurried to a concert of the Schuppanzigh String Quartet to listen to Haydn's quartets. Ibid., 39.

9. He writes about Haydn's relations as follows: "Glauben Sie nicht, daß ich nach der Art eines genauen Biographen Ihnen jetzt alle Namen und Schicksale aufzählen werde; ich bin niemals ein Fliegenfänger gewesen." Carpani, Haydn, 42.

10. See the different versions of the history of genesis of the Farewell Symphony: "Man sieht daraus, wie weit man den Berichten von Augenzeugen glauben kann!” Carpani, Haydn, 120-122. 
There is no doubt that Carpani raises his questions and arranges the answers according to the highest musical aesthetical categories of the time to make up an intelligent order. His view is basically the tinged Haydn-picture of an Italian patriot, a free spirit, who is deeply democratic at heart and sympathizes secretly with the European revolutions.

The thus depicted Haydn, who used Italianised signature in a considerable amount of his manuscripts ${ }^{11}$ as Giuseppe Haydn, though he was christened Franz Joseph, Carpani's "namesake", grew up listening not only to the southern German folk music treasure in his parents' home and the mixed nationalities' folk music along the border but to the centuries-old Catholic choral music as well and came under the spell of the art of the great Italian masters in his early childhood. He was fascinated by a world where all musical manifestations, even the rules acquired unaided from the theoretical works of Fux ${ }^{12}$ proclaim, just as all Italian masters did since Palestrina, the supremacy of the Melody. ${ }^{13}$ Carpani saw in Haydn, who was completely at ease with the works of the Italian masters, the organic continuation of the culture of his own people.

For the sake of being able to express it he was forced to turn to steady make-believe, a writer's playful inventiveness. He set to the task equipped with great talent and comprehensive knowledge of musical aesthetics and the history of art.

The date of the fictitious letters written in Vienna, Baden and Banat varies between 15 April 1808 and 15 September 1811. Vienna, the capital of the Danubian Monarchy and Baden, the popular spa town close to Vienna can even have been scenes of idyllic events but "Banat", the third location mentioned in five letters was a geographic-historical region on the south-eastern part of the Carpathian Basin suggesting unexpected disturbances, a menace on historical scale. It is presumable that Carpani joined the Habsburg Court when it fled from Napoleon in 1809 to the administrative centre of Banat called Temesvár [now Timișoara, Romania] where the Habsburg crown jewels, the treasures of museums and libraries, and the Holy Crown of Hungary were kept. ${ }^{14}$ We should not be misled: it was a complete cataclysm indeed and when Haydn's biographer, the eyewitness and citizen, looks

11. The composer's name is written as "Giuseppe Haydn" on 159 of the 372 items in the Haydn collection of the Hungarian National Széchényi Library.

12. See "Elementarbuch der verschiedenen Gattungen des Contrapunkts. Aus den grösseren Werken des Kappm. Fux, von Joseph Haydn zusammengezogen. Esterhazy 22. 7tbr. 1789. F. C. Magnus" - The manuscript of the theory of counterpoint compiled by Haydn on the basis of Fux's works is preserved in the Music Collection of the National Széchényi Library. Quoted by Jenő Vécsey, Haydn müvei az. Országos Széchényi Könyvtár gyüjteményében [Haydn's works in the collection of the National Széchényi Library], (Budapest: Akadémiai Kiadó, 1959), 52-53. - Fux occupied the first place for Haydn, in addition to the theoretical works by Mattheson, Carl Philipp Emmanuel Bach, and Kirnberger: "Sich selbst und seinem harmonischen Koran überlassen, hatte er diesen auf mehrere Notizbücher verteilt, die er immer bei sich trug." Carpani, Haydn, 50.

13. In his discussion of melody, the soul of music, Carpani quotes Haydn as saying "Findet eine schöne Melodie, und jede Komposition ist schön und wird sicherlich gefallen” Ibid., 54.

14. Kind information of Dr. László Pászthy, head of the Map Collection of the Hungarian National Széchényi Library, Budapest. 
back from the Master's last days harassed by the menace of war he illustrates the comforting example of Haydn's genius by means of classical Greek-Latin authors, the Bible, the Quran and the truth of everlasting values spanning millennia. ${ }^{15}$

Before thinking that we will have to read of an apotheosis filled with pathos we hit upon enjoyable thoughts, musical jokes, and intellectual hide-and-seek at every turn. Nevertheless, the reader starts becoming suspicious when evident mistakes, slips of the pen in writing names emerge. For example, Carpani spells the name of Mme Polzelli ${ }^{16}$ deliberately incorrectly and mentions her as a mistress deceased during the Master's lifetime, although she lived until 1830. One has the feeling that a genuine rascal hides among the lines. The questioned Master and even the questioner tease us and observe maliciously if we succeed in catching him.

There are just a few music examples in the whole volume, yet the clefs and key signatures are sloppily placed in all of them. In the first one the writer illustrates a music quotation written in C minor and supported by Haydn's explanation - "Schlagen Sie auf dem Klavier ein c-moll an ..." - with a melody in E major. ${ }^{17}$ One of the dramaturgical climaxes of the discussions about the power of music is when Carpani attests to the marvellous, healing effect of Haydn's alleged Mass in $\mathrm{B}$ minor heard live. Though the reader readily believes that listening to a masterpiece may cure physical ailments, he will get annoyed on realizing that none of Haydn's fourteen masses was composed in B minor. ${ }^{18}$ The number of misleading data and examples is enormous indeed. It is therefore futile to try to weigh all statements of this book on the precision scales of present-day Haydn-scholarship. It may happen that other sources also corroborate that the cited biographical evidence was actually so or may have been so as interpreted by Carpani. On the other hand, it is also possible that Haydn himself was mistaken or remembered wrongly when he informed his biographer of facts and data to be corrected later.

One may ask which particulars of this vigorous Haydn portrait compiled by an excellent writer should be regarded as true? The path of life as described by Carpani can be substantiated from other sources as well: the unbelievable ambition and zeal of the Viennese choir-boy coming from extreme poverty and becoming

15. See e.g. the two quotations from Horace cited by Haydn in the second letter: "Quantum generi demas, virtutibus addas. (Was dir an Geburt fehlt, fügst du an Fähigkeiten hinzu)"; "Sume superbiam quaesitam meritis. (Sei stolz auf den Ruhm, den du deinem Verdienst verdankst)." Carpani, Haydn, 41, 45.

16. On page 103, Carpani writes the name of Haydn's mistress Luigia Polzelli as Madame Boselli. Later, on page 207, he writes "Doch als seine Freundin, Madame Polzelli, gestorben war [...]" declaring the same person dead, even though Luigia Polzelli lived until 1830 and carried on a lawsuit for Haydn's inheritance.

17. The music example quoted on page 59 is known from Haydn's London notes. It was the melody Haydn heard at St. Paul's Cathedral, London sung by 4,000 children: "[...] keine Musik rührt mich zeitlebens so heftig als diese andachstvolle und unschuldige." - Quoted after Dénes Bartha by Manfred Huss, Joseph Haydn. Klassiker zwischen Barock und Biedermeier (Eisenstadt: Roetzer, 1984), 188.

18. "Als ich 1799 in Wien war, erkrankte ich an einem Fieber [...] Es war St.-Annen Tag, und man führte in der ihr geweihten Kirche eine Messe von Haydn auf, die in h-Moll, welche ich noch nicht gehört habe. [...] Eine ungewohnte Heiterkeit überkam mich, und als die Messe geendet hatte, verließ ich die Kirche gesund und heil." Carpani, Haydn, 141. 
a "self-made man" 19 through self-education. This career is all the more fascinating as it lacked the background of a respectable family. "Ihre Vorfahren wurden geboren, lebten vor sich hin und starben; das ist ihre ganze Biographie." ${ }^{20} \mathrm{He}$ was not a child prodigy like Mozart; in childhood and youth he was a plain-looking, humbly-clad existence on the periphery of society. Yet his beautiful, captivating eyes, his clever, witty remarks given to the questions of his environment, his incredible zeal to overcome his deficiencies through self-education and the systematic study of the history of European music and the greatest works of his contemporaries promised him a great future.

To put Haydn's greatness into proper historical perspective, Carpani outlined the earlier state of music per country and workshop in all genres in which Haydn created something new: he renewed the symphony, made the string quartets reach classical perfection and in the field of church music; besides, he quoted the from time to time different conclusions of the historical treatises on the beauty of music. This was the only way to prove that this young man of genius expelled from the boarding-school of the Stephanskirche of Vienna was completely alone in the hustle and bustle of the imperial metropolis from the age of $17 \mathrm{on}$. Yet endowed with modesty, adaptability, exceptional fantasy and curiosity for all innovation he wished to have - just like the great natural scientists of his time - an experimental workshop, an orchestra where he could experiment with instruments to his liking and where he could find a place for his early budding composer's ambitions. After the occasional remuneration of church service, street music, and instruction, the only realistic way to find a safe subsistence was the patronage of a music-lover feudal lord.

Following the formative years in the household of Baron von Fürnberg and Count Morzin, Haydn entered in 1761 into the service of the Hungarian Paul Anton Esterházy (1711-1762), member of one of the richest aristocratic families of Europe, who also earned the title of Imperial Count. From that time on Haydn's career was secured for decades. The framework of the prince's household, the church music at Kismarton [now Eisenstadt, Austria], the occasional celebrations at court, the "commissions" to give regular court concerts - the possibilities to produce his compositions and the lessons drawn from imported works purchased by means of an excellent network of agents and in many instances at Haydn's advice - all these created extraordinary circumstances for a creative artist of Haydn's stature. He had an 18-member orchestra at his disposal he could experiment with as he pleased and stimulate to productions in every possible combination. ${ }^{21}$ In ma-

19. "Als er schon recht betagt und mit Ehren überhäuft war, hat er mir selbst gestanden, daß er sich nicht erinnern könne, an einem Tag weniger als sechzehn Stunden gearbeitet zu haben, ja manchmal sogar achtzehn." Carpani, Haydn, 45-46.

20. Carpani, Haydn, 40.

21. Carpani writes: "Ich habe einige der Musiker, die mit ihm auf Schloß Esterházy lebten, sagen hören, daß Haydn seine Arbeit oft unterbrach, das Orchester versammelte und bestimmte Passagen von verschiedenen Instrumenten ausprobieren ließ.” Carpani, Haydn, 71. 
ture years his strict agenda was supported - as an excellent subject of Emperor Francis II - by an exemplary lifestyle: sobriety, restraint, 16 to 18 hours of continuous work at his desk. ${ }^{22}$ The reader wonders: was it really so in all phases of his life?

Whoever is familiar with Haydn's daily duties in the service of the Esterházy family, knows his official documents and sheet music sources will soon realize that Carpani's Haydn biography focuses almost entirely on the praise of the grand master of symphony and string quartet, the reformer of Catholic church music, and the composer of the oratorios The Creation and The Seasons. He omits, however, from Haydn's oeuvre the important phase of his life spent at Eszterháza, the "Hungarian Versailles", where he ran between 1776 and 1790 as conductor and opera composer a whole operatic enterprise built upon the repertory of Venetian-Neapolitan opera composers. Carpani, the censor of the Venetian theatres, had nothing to say of Haydn's operas: he was either unfamiliar with or had little knowledge of them and formed his judgment from hearsay. In reality, he avoided evaluating the operatic productions of European rank at Eszterháza. He passed a summary judgement on him: "Er mäßigte seine Einbildungskraft, verminderte seinen instrumentalen Reichtum, hielt sein lebhaftes Brio zurück [...] Er diente also dem Dichter wie dem Sänger - doch er war nicht mehr Haydn.”23

We may only presume: did it make Carpani feel awkward that the golden age of the opera in Hungary unfolding as a rival to the Imperial capital between 1776 and 1790 brought - apart from Haydn's works for the stage - the greatest operatic composers of Italy (Cimarosa, Sarti, Paisiello, Piccinni, Anfossi) within easy reach for Haydn and the princely household? Or did Haydn himself become mistrustful of his conversation partner?

One of the major issues of the aesthetics of the time was whether music had contents, was able to express anything even if it was of lesser concern than to the followers and opponents of programme music later, in the middle of the $19^{\text {th }}$ century. Haydn quotes examples of programs that served him as musical inspirations for elaborating some of his works. He dwells upon the story of a voyage to America featuring the adventures of a poor man who tries his fortune in America. ${ }^{24}$ It is left, however, untold which alleged Haydn symphony would certain sections of the description suit as a programme.

In another place Haydn reveals the musical devices he used in The Creation to evoke the birth of Light. The model was the image of the Creator who struck light by holding a flint-stone in one hand and steel in the other, then rubbing the two together. ${ }^{25}$ Carpani was somewhat incredulous about this suggestive baroque

22. "Wenn der Mensch mit sich selbst im Reinen ist, trägt er glückliche Ideen in seiner Brust. [...] Er mußte sich zuerst auf das Beste frisieren und so elegant kleiden, als ob er ausgehen wollte [...]" Carpani, Haydn, 84-85.

23. Ibid., 133.

24. Ibid., 85.

25. Ibid., 87-89. 
image. Some paragraphs later Haydn admitted that he had invented the story to satisfy the curiosity of simpletons.

There is still more piquancy in the playful ambiguity of Carpani's description of how Haydn caricatured - not explicitly but hidden among the lines - the name of the Austrian statesman Franz Josef Graf Saurau (1760-1832), who crushed the Austrian and Hungarian Jacobin movements. He was the Emperor's counsellor, the governor of Lombardy for some time, commissioner of the anthem Gott erhalte meant to forge the unity of the peoples of the Empire. Although Gott erhalte was one of the greatest successes in Haydn's life - a melody he played on the piano under the threat of Napoleonic war in the last days of his life -, his genuine respect for his country and his ruler did not hinder him from ornamenting a wall in his room with a tapestry glued together from canons. ${ }^{26}$ It contained an alleged woman-mocking song the text of which was stained by an ugly inkblot, a "Sau".

In this splendid Haydn biography all these playful indecencies find room beside the ceremonial preparations for composing, the festive attire and the freshly curled wig, the diamond ring given to Haydn by Frederick II, King of Prussia and put on out of superstition ${ }^{27}$ while his one-time master, Prince Nikolaus Esterházy "the Magnificent" was the champion of valiance against the King of Prussia in 1757.

In the London anecdotes the world opens all of a sudden. The ideals in life of a citizen from the Austrian Empire are penetrated with the sensations of the geographic-scientific discoveries, ${ }^{28}$ the revolutionary views of social equality and, even if unsaid, with the shocking new ideas of the theses of the American Declaration of Independence. A new world gets outlined in which man is no more subordinated to another man as a servant, where the chief Melody of a symphony is no more entrusted to a single selected instrument but is distributed equally among the individual instruments of the orchestra ${ }^{29}$ and where in the string quartet four friends, four parties of equal rank make music for their own pleasure, ${ }^{30}$ everybody in their own idiom and according to their best knowledge, in Harmony.

26. "Sein Schlafzimmer war mit komischen und bizarren Kanons tapeziert. Darunter befand sich auch einer, in dem er im Kontrapunkt über seine kapriziöse Frau herfiel. Die Worte waren etwa: Hier liegt Hausbau mit seiner Frau. Der maliziöse Komponist ließ jedesmal, wenn in dem Kanon das Wort Frau auftaucht, mit Absicht einen großen Tropfen Tinte fallen. Sie müssen aber wissen, daß diese Sorte von Flecken, die das Papier beschmutzten, im österreichischen Dialekt als 'Sau’ bezeichnet wird.” Carpani, Haydn, 124.

27. "Friedrich von Preußen hatte ihm einen Ring geschenkt, und Haydn gestand offen, daß ihm, wenn er zufällig vergessen hatte, ihn anzustecken, keine Einfälle gekommen seien, daß also seine schöpferische Ader ohne dieses sprechende Zeugnis der Wertschätzung einer so erlauchten Persönlichkeit am Vertrocknen war." Carpani, Haydn, 85.

28. Haydn visited Friedrich Wilhelm Herschel (1738-1822), the astronomer, who discovered the planet Uranus. Carpani, Haydn, 215.

29. "Haydn glaubte, daß er einen viel besseren Effekt erzielen würde, wenn er die Melodie auf alle Instrumente verteilte [...] In seinem Orchester gab es keine Herren und Knechte; [My italics, Katalin Szerzö] alle waren Finger derselben Hand, alle Blumen, die denselben Garten bildeten.” Carpani, Haydn, 68.

30. "Einer meiner Freunde stellte sich beim Hören eines Quartetts von Haydn vor, einer Unterhaltung von vier Freunden beizuwohnen" Carpani, Haydn, 107. 
At Windsor the king and the queen of Great Britain wanted to take the master into their service but Haydn declined the honour with reference to his heart-felt loyalty to his country and the Esterházy family. He proudly acknowledged the conferment of the Oxford honorary doctorate by saying this distinction had not been given to Händel either, whom he held in high esteem. ${ }^{31}$ Once Haydn made the following remark on Händel to Carpani: "Dieser ist der Vater von uns allen."32 Can a musician be more honoured by his contemporaries?

By the end of his life, Haydn had considerable riches, a family house of his own and held several distinctions. Yet his human portrait would be incomplete without mentioning the successes of his last great official appearances in Vienna, the genuine human apotheosis of the Master who attended the performances of The Creation and The Seasons in increasingly weak physical condition and blessed gratefully the performers, his friends and the audiences. ${ }^{33}$ These details, the most beautiful chapters of the book, bear witness with the authenticity of an eyewitness and excellent musician to Haydn's nicest gestures in old age. They were the manifestations of an artist who was motivated by deep religious faith to achieve the greatest human efforts ${ }^{34}$ all his life and whose daily supper consisted of bread and wine, the signs of the Lord's Supper without his telling so. The wine was mostly a wine of Tokaj (a region in North-East Hungary famous for its wine), ${ }^{35}$ which is in the belief of the Hungarians the king of wines and, the wine of kings...

31. Cf. the story of the royal invitation and the decoration at Oxford. Carpani, Haydn, 214-215.

32. The remark is all the more interesting as it is one of the few occasions when Carpani indicated the place and the circumstances under which these words were uttered: "Ich befand mich während einer Aufführung von Händels Messias im Palais Schwarzenberg neben Haydn, und voll Bewunderung für einen von Händels großartigen Chören sagte er mir." Carpani, Haydn, 81.

33. The Creation was performed in Carpani's Italian translation in the hall of the University of Vienna on 27 March 1808. About 2000 people, concert-goers and singers presented the oratorio conducted by Salieri. "Ich hatte den ersten Platz direkt hinter Haydn." - writes Carpani. Carpani, Haydn, 222-223.

34. See e.g. Haydn's evidence on the time of composing The Creation. "'Als ich die Schöpfung schrieb', sagte er mir, 'fühlte ich mich so von religiösen Gefühlen durchdrungen, daß ich mich, ehe ich an die Arbeit ging, mit einem leidenschaftlichen Gebet an Gott wandte'." Carpani, Haydn, 242.

35. "Auch nahm er immer, wenn sich die Gelegenheit dazu ergab, eine Glas Tokayer [...] zu sich." Carpani, Haydn, 219. 